\title{
The Effect of Oxygen on Tetrathionate Reductase Activity and Biosynthesis
}

\author{
By F. K APRÁLEK \\ Department of Microbiology, Charles University, Prague 2, Czechoslovakia \\ AND F. PICHINOTY \\ Laboratoire de la Chimie Bactérienne, C.N.R.S., Marseille 9, France
}

(Accepted for publication 2 April 1970)

SUMMAR Y

Cyanide (I $\mathrm{mM}$ ) strongly inhibited aerobic respiration, and 2,4 dinitrophenol $(0.2 \mathrm{~mm})$ apparently uncoupled oxidative phosphorylation, in nongrowing Citrobacter. At these inhibitor concentrations, anaerobic tetrathionate reductase activity was not much affected. Aeration inhibited tetrathionate reductase activity; $0.2 \mathrm{~mm}-2,4$ DNP did not influence oxygen inhibition, but I $\mathrm{mM}-\mathrm{KCN}$ restored the reductase activity quantitatively. The process of aerobic respiration rather than the oxygen molecule itself therefore inhibits tetrathionate reductase activity. Induced synthesis of reductase required anaerobic conditions. Cyanide and 2,4 DNP allowed anaerobic synthesis of reductase; aeration prevented it. This effect of oxygen was abolished neither by KCN nor by 2,4 DNP. Oxygen therefore represses the synthesis of tetrathionate reductase directly.

\section{INTRODUCTION}

That some facultative anaerobic bacteria reduce tetrathionate to thiosulphate was discovered by Pollock and co-workers (Pollock, Knox \& Gell, 1942; Pollock \& Knox, 1943; Knox, Gell \& Pollock, 1943). The reaction was quantitative:

$$
\mathrm{S}_{4} \mathrm{O}_{6}^{2-}+2 \mathrm{H}=2 \mathrm{~S}_{2} \mathrm{O}_{3}^{2-}+2 \mathrm{H}^{+}
$$

$\mathrm{H}^{+}$and thiosulphate accumulated in the medium. Later, Knox \& Pollock (1944) demonstrated that the enzyme responsible for the reduction of tetrathionate was both specific and inducible, the sole known substrate and inducer being tetrathionate. Tetrathionate reduction is widespread among the facultative anaerobes and has some taxonomic and diagnostic value (Le Minor \& Pichinoty, I963; Nicolle \& Le Minor, I965; Le Minor, I967; Papavassiliou, Samaraki-Lyberopoulou \& Piperakis, 1969). Discussing the possible physiological role of tetrathionate reductase in bacteria, Pollock and co-workers concluded that it may be a form of anaerobic respiration analogous to the reduction of nitrate to nitrite. This analogy was supported by the finding (Pollock \& Knox, 1943) that tetrathionate reductase activity, like nitrate reductase activity (Stickland, I93I), was reversibly inhibited by aeration. Pichinoty \& Bigliardi-Rouvier (1963) found that oxygen not only inhibited the activity of tetrathionate reductase but also repressed its synthesis.

Our investigation attempts to clarify the mechanism of this dual action of oxygen in washed non-growing organisms. Tetrathionate reductase is not the sole bacterial enzyme which is inhibited and repressed by oxygen (Fowler, I95I ; Pichinoty, I965; Gray, Wimpenny, Hughes \& Mossman, 1966; Gray, Wimpenny \& Mossman, 1966), 
thus results reported here are also a contribution to the understanding of a general phenomenon called the 'oxygen effect' (Pichinoty, 1965).

\section{METHODS}

Micro-organism and cultivation. The original strain isolated by Pollock (1946) and labelled ' 1433 ', recently identified by Sedlak \& Slajsova (I967) as Citrobacter, was grown on a reciprocating shaker at $30^{\circ}$ in the following medium (g./l. dist. $\mathrm{H}_{2} \mathrm{O}$ ): $\mathrm{Na}_{2} \mathrm{HPO}_{4}$. I $2 \mathrm{H}_{2} \mathrm{O}, 3.57 ; \mathrm{KH}_{2} \mathrm{PO}_{4}, 0.98 ; \mathrm{MgSO}_{4} .7 \mathrm{H}_{2} \mathrm{O}, 0.03 ; \mathrm{NH}_{4} \mathrm{Cl}, 0.50$; traces of $\mathrm{FeSO}_{4}$ and $\mathrm{CaCl}_{2}$; lactose, $2 \cdot 0$; yeast extract Difco, 0.5 ; Casamino acids Difco, 0.5 ; bacto-peptone Difco, 0.5 . The $\mathrm{pH}$ was adjusted to 6.8 before sterilization for $20 \mathrm{~min}$. at $127^{\circ}$; lactose was sterilized separately. If organisms possessing tetrathionate reductase activity were required, a solution of $\mathrm{I} \cdot 0 \mathrm{~g} . \mathrm{K}_{2} \mathrm{~S}_{4} \mathrm{O}_{6} /$. (sterilized by filtration) was added as inducer. After $15 \mathrm{~h}$. the bacteria (by then in the stationary phase) were harvested, washed twice and resuspended in distilled water.

Although aerobic cultivation represses the synthesis of tetrathionate reductase (Pichinoty \& Bigliardi-Rouvier, 1963), organisms containing much tetrathionate reductase can be grown as described above because the concentration of dissolved oxygen decreased during growth of the culture and was practically zero at the high bacterial concentrations reached towards the end of the exponential growth phase. When the organisms were harvested, tetrathionate was still present in the medium indicating that inducer had been present throughout growth. This mode of cultivation had the advantage of a fourfold greater yield of active organisms compared with anaerobic cultivation.

Tetrathionate reductase activity. This was measured anaerobically as follows (Pollock \& Knox, I943; Kaprálek, Pichinoty \& Riegrová, 1969): A buffer solution containing a source of hydrogen and electrons (e.g. glucose) and washed bacterial cells was warmed to $37^{\circ}$ and $\mathrm{K}_{2} \mathrm{~S}_{4} \mathrm{O}_{6}$ was added at time zero $\left(t_{0}\right)$. The composition of the test systems and the concentrations of components are given with the appropriate figures. This manner of static incubation of $20 \mathrm{ml}$. of thick bacterial suspension in an I $8 \mathrm{~mm}$. test-tube, provided adequately anaerobic conditions and was equivalent to incubation in a vacuum in a Thunberg tube or to incubation with bubbling $\mathrm{O}_{2}$-free nitrogen through the solution. If aerobic conditions were required, Io vol. of air/vol. medium $/ \mathrm{min}$. was sparged through the system. At intervals, I ml. samples were transferred to $3 \mathrm{ml} .96 \%(\mathrm{v} / \mathrm{v})$ ethanol or into I ml. of $5 \%(\mathrm{w} / \mathrm{v})$ trichloracetic acid to stop the reaction. Thiosulphate produced was then assayed iodometrically. From these data the initial velocity of tetrathionate reduction $\left(v_{t}=\mu\right.$ mole $\mathrm{K}_{2} \mathrm{~S}_{4} \mathrm{O}_{6}$ reduced $/ \mathrm{h} . / \mathrm{mg}$. dry wt) was calculated as the product of the first-order reaction rate constant and initial tetrathionate concentration (Kaprálek et al. 1969) and taken as the measure of tetrathionate reductase activity. The micro-organism used in our work did not reduce thiosulphate enzymatically, and therefore the thiosulphate found in the medium corresponded quantitatively to the tetrathionate reduced.

Induction of tetrathionate reductase. This was carried out in a similar manner to the assay above. Exact experimental conditions are mentioned under relevant figures.

Rate of oxygen uptake. This was measured using a Warburg apparatus at $37^{\circ}$, with air as gas phase. Results were expressed as $Q_{\mathrm{o}_{2}}\left(\mu \mathrm{l}\right.$. $\mathrm{O}_{2}$ consumed $/ \mathrm{h} . / \mathrm{mg}$. dry wt). The experiments with $\mathrm{KCN}$ were carried out using the method of Robbie (1946). 


\section{RESULTS}

The inhibitory effect of oxygen on tetrathionate reductase activity

The inhibition of tetrathionate reductase activity by oxygen is demonstrated in Fig. I. The inhibition disappeared immediately after aeration ceased. Nothing is known about the mechanism of this reversible inhibitory effect of oxygen. Three possibilities may be considered.

(I) Oxygen may directly and reversibly inactivate the tetrathionate reductase molecule. In this case its inhibitory effect would depend only on the concentration of oxygen in solution.

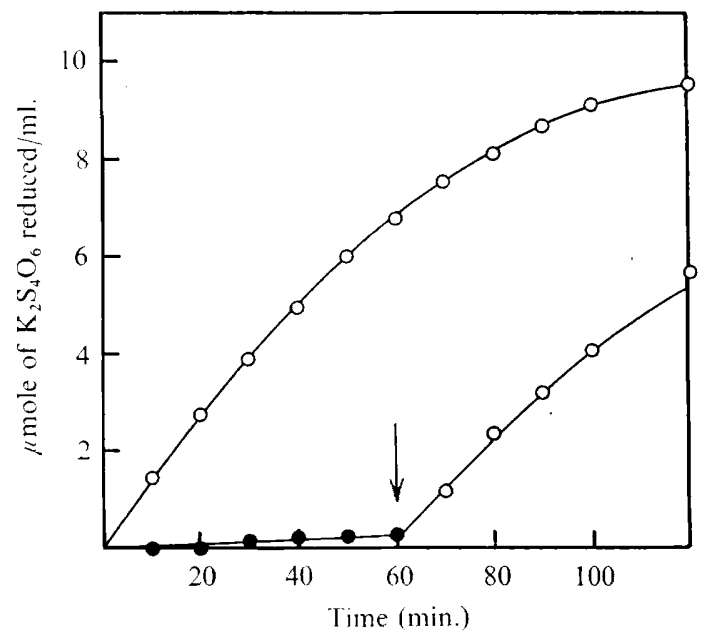

Fig. I. Effect of aeration on the tetrathionate reductase activity of washed organisms previously grown in the presence of $\mathrm{K}_{2} \mathrm{~S}_{4} \mathrm{O}_{6}$. $0.16 \mathrm{M}$-phosphate buffer, $\mathrm{pH} 6.8$; glucose $50 \mu$ mole/ $\mathrm{ml}$; $\mathrm{K}_{2} \mathrm{~S}_{4} \mathrm{O}_{6} 25 \mu \mathrm{mole} / \mathrm{ml}$; chloramphenicol $50 \mu \mathrm{g} . / \mathrm{ml}$.; washed organisms equiv. I. $5 \mathrm{mg}$. dry $\mathrm{wt} / \mathrm{ml}$; final volume $20 \mathrm{ml}$. $\mathrm{O}-\mathrm{O}$, Anaerobically; $-\mathrm{O}$, aerobically; arrow indicates the time the aeration was stopped.

(2) The oxygen itself may not be the inhibitor. It may act indirectly in that electrons are preferentially transferred to it for aerobic respiration. If so, the inhibitory effect would not depend on the dissolved oxygen concentration but on the organism's $Q_{o_{2}}$.

(3) Aerobic respiration brings about oxidative phosphorylation leading to an increased rate of ATP formation and decreased steady state level of ADP. Tetrathionate respiration might thus be inhibited in a manner analogous to the aerobic inhibition of glucose fermentation (the Pasteur effect), i.e. indirectly through the ratio of ATP to ADP. If so, inhibition by oxygen would depend neither on its concentration in solution nor on the $Q_{\mathrm{o}_{2}}$ activity, but on the ability of the organisms to perform aerobic oxidative phosphorylation.

Fig. 2 shows that 2,4 dinitrophenol did not influence the tetrathionate reductase activity at concentrations $<0.25 \mathrm{mM}$, whereas from 0.0 I mM it stimulated the respiratory activity as much as $40 \%$. At such concentrations 2,4 DNP uncouples phosphorylation from oxidation and thus usually causes an increase in the rate of oxygen consumption (James, I953; Dolin, I96r ; Slater, 1963). It is probable that the inhibitor acted similarly at $0.2 \mathrm{~mm}$ in our experiments. This conclusion is supported by growth experiments 
(Fig. 2). The aerobic growth rate with $0 \cdot 2 \mathrm{mM}-2,4 \mathrm{DNP}$ was equal to the rate of anaerobic growth. Nevertheless, no concentration of 2,4 DNP tested abolished the inhibitory effect of aeration on tetrathionate reductase activity (Fig. 2, the lowest curve), so it is probable that the inhibitory effect of oxygen on reductase activity was not determined by the ability of organisms to carry out aerobic oxidative phosphorylation. Thus the activity of tetrathionate reductase seems not to be controlled by the intracellular levels of ADP and ATP.

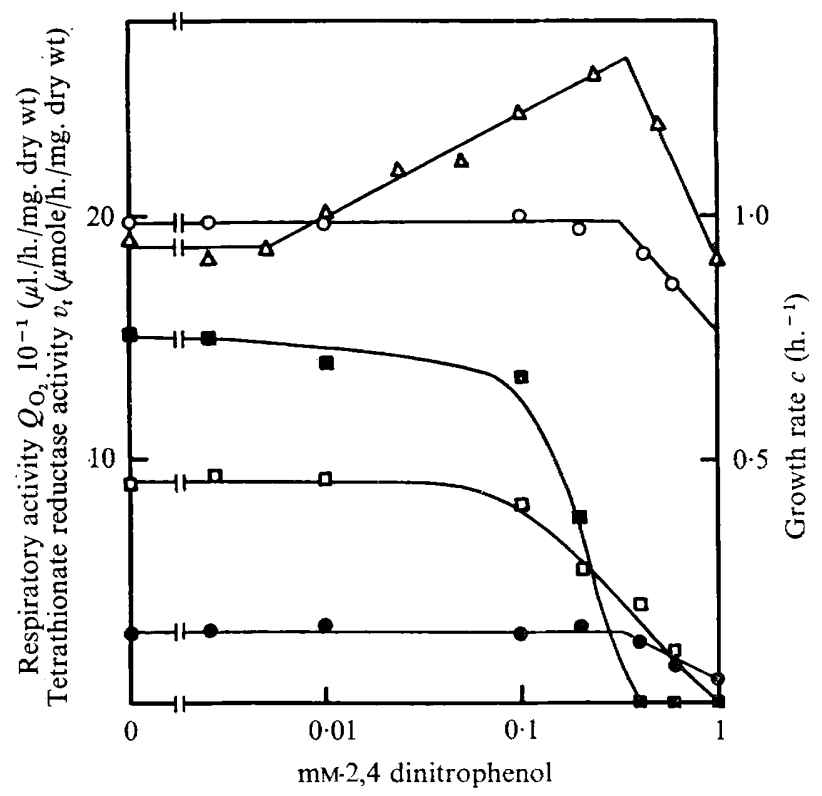

Fig. 2. Effect of 2,4 dinitrophenol on the respiratory activity $Q_{\mathrm{O}_{2}}(\mu \mathrm{l} . / \mathrm{h} . / \mathrm{mg}$. dry wt) (0.16 M-phosphate buffer, pH 6.8; glucose $50 \mu \mathrm{mole} / \mathrm{ml}$; chloramphenicol $50 \mu \mathrm{g} . / \mathrm{ml}$.; washed organisms equiv. $0.364 \mathrm{mg}$. dry wt/ml.), on the tetrathionate reductase activity $v_{t}$ ( $\mu$ mole $/ \mathrm{h}$./mg.) (0.16 M-phosphate buffer, pH 6.8; glucose $50 \mu$ mole $/ \mathrm{ml}$; $\mathrm{K}_{2} \mathrm{~S}_{4} \mathrm{O}_{6} 25 \mu$ mole $/$ $\mathrm{ml}$; washed organisms equiv. $2 \mathrm{mg}$. dry wt $/ \mathrm{ml}$.; chloramphenicol $50 \mu \mathrm{g} . / \mathrm{ml}$.; final volume $20 \mathrm{ml}$.) and on the growth rate $c=\left(\log _{2} x_{2}-\log _{2} x_{1}\right) /\left(t_{2}-t_{1}\right)\left(\mathrm{h} .^{-1}\right)\left(\mathrm{Na}_{2} \mathrm{HPO}_{4} \cdot \mathrm{I}_{2} \mathrm{H}_{2} \mathrm{O}\right.$, 3.57 g.; $\mathrm{KH}_{2} \mathrm{PO}_{4}, 0.98 \mathrm{~g}$.; $\mathrm{MgSO}_{4} .7 \mathrm{H}_{2} \mathrm{O}, 0.03 \mathrm{~g}$.; $\mathrm{NH}_{4} \mathrm{Cl}, 0.50 \mathrm{~g} ; \mathrm{FeSO}_{4}$ and $\mathrm{CaCl}_{2}$, traces; glucose, $2.0 \mathrm{~g}$; ; distilled water ad $1000 \mathrm{ml}$., pH 6.8). - - - , Tetrathionate reductase activity anaerobically; $-\bullet$, tetrathionate reductase activity aerobically; $\square-\square$, growth rate anaerobically (in $\mathrm{O}_{2}$-free nitrogen); - growth rate aerobically (reciprocating shaker); $\triangle \longrightarrow \triangle$, respiratory activity $Q_{O_{2}}$.

Fig. 3. shows that $\mathrm{KCN}$ (up to I $\mathrm{mm}$ ) did not influence the activity of tetrathionate reductase anaerobically but strongly inhibited the aerobic respiration. However, inhibition of tetrathionate reductase activity by aeration did not occur in the presence KCN (Table I). Figure 4 shows a direct correlation between respiratory activity and tetrathionate reductase activity in the presence of oxygen. A graphical extrapolation (Dixon, 1953) of the data of this figure gave a dissociation constant $\left(K_{\mathrm{i}}\right)$ of $0.02 \mathrm{~mm}$. Figure 5 shows the instantaneous (curve 2) and reversible (curves, 3, 3') nature of the effect of cyanide.

Later experiments using carbon monoxide verified the results found with cyanide. Table 2 shows inhibition of respiration by $\mathrm{CO}$ : the sensitivity of aerobic respiration to $\mathrm{CO}$ was very low and $Q_{\mathrm{O}_{2}}$ values below $70 \%$ of the control were not obtained. 
Table 3 shows that $\mathrm{CO}$ similarly to $\mathrm{KCN}$ reduced the inhibition of tetrathionate reductase by oxygen, but only partially, in line with its partial inhibition of the aerobic respiration. Tetrathionate reductase activity itself was not influenced by $\mathrm{CO}$.

Thus cyanide and $\mathrm{CO}$ abolished the inhibition of tetrathionate reductase activity by oxygen by inhibiting aerobic respiration. Even in the presence of dissolved oxygen the

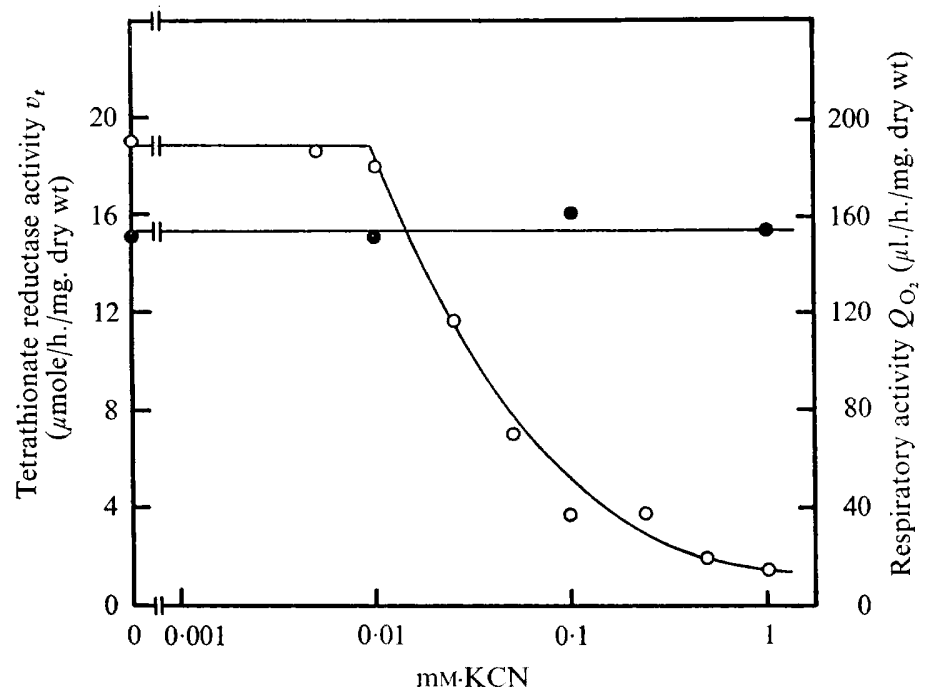

Fig. 3. Effect of $\mathrm{KCN}$ on the respiratory activity $Q_{\mathrm{O}_{2}} \bigcirc-O(\mu \mathrm{l} / \mathrm{h}$./mg.) (0.16 M-phosphate buffer, $\mathrm{pH} 6.8$; glucose $50 \mu$ mole $/ \mathrm{ml}$.; chloramphenicol $50 \mu \mathrm{g} . / \mathrm{ml}$.; washed organisms equiv. $0.285 \mathrm{mg}$. dry $\mathrm{wt} / \mathrm{ml}$.) and on the tetrathionate reductase activity $v_{t}$ ( $\mu$ mole/h./mg.) (0.16 M-phosphate buffer pH 6.8; glucose $50 \mu$ mole $/ \mathrm{ml}$.; $\mathrm{K}_{2} \mathrm{~S}_{4} \mathrm{O}_{8} 25 \mu$ mole/ $\mathrm{ml}$.; washed organisms equiv. I mg. dry wt $/ \mathrm{ml}$; chloramphenicol $50 \mu \mathrm{g} . / \mathrm{ml}$; final volume $20 \mathrm{ml}$.).

Table I. Inhibition of tetrathionate reductase activity of washed Citrobacter by oxygen in the presence of $K C N$

0.I6 M-phosphate buffer, pH 6.8; glucose $50 \mu$ mole/ml.; $\mathrm{K}_{2} \mathrm{~S}_{4} \mathrm{O}_{6} 25 \mu \mathrm{mole} / \mathrm{ml}$.; washed organisms equiv. I mg. dry wt $/ \mathrm{ml}$; chloramphenicol $50 \mu \mathrm{g} . / \mathrm{ml}$.; final volume $20 \mathrm{ml}$.

\begin{tabular}{|c|c|c|}
\hline \multirow[b]{2}{*}{$\mathrm{KCN} \mathrm{mm}$} & \multicolumn{2}{|c|}{$\begin{array}{l}\text { Tetrathionate reductase } \\
\text { activity } v_{t}(\mu \text { mole/h./mg. })\end{array}$} \\
\hline & Anaerobically & Aerobically \\
\hline 0 & $9 \cdot 9$ & 0.0 \\
\hline 0.1 & I I 6 & $9 \cdot 4$ \\
\hline$I \cdot O$ & I I 9 & $8 \cdot 8$ \\
\hline
\end{tabular}

tetrathionate reductase system remained active because the transport of electrons to oxygen was blocked. Thus it was not oxygen itself, but aerobic respiration (the preferential transport of electrons to oxygen) that inhibited the tetrathionate reductase activity.

The question arose whether the reverse was true: could anaerobic respiration of tetrathionate inhibit aerobic respiration? Table 4 indicates an affirmative answer: the anaerobic respiration of tetrathionate inhibited the aerobic respiration of oxygen. It 


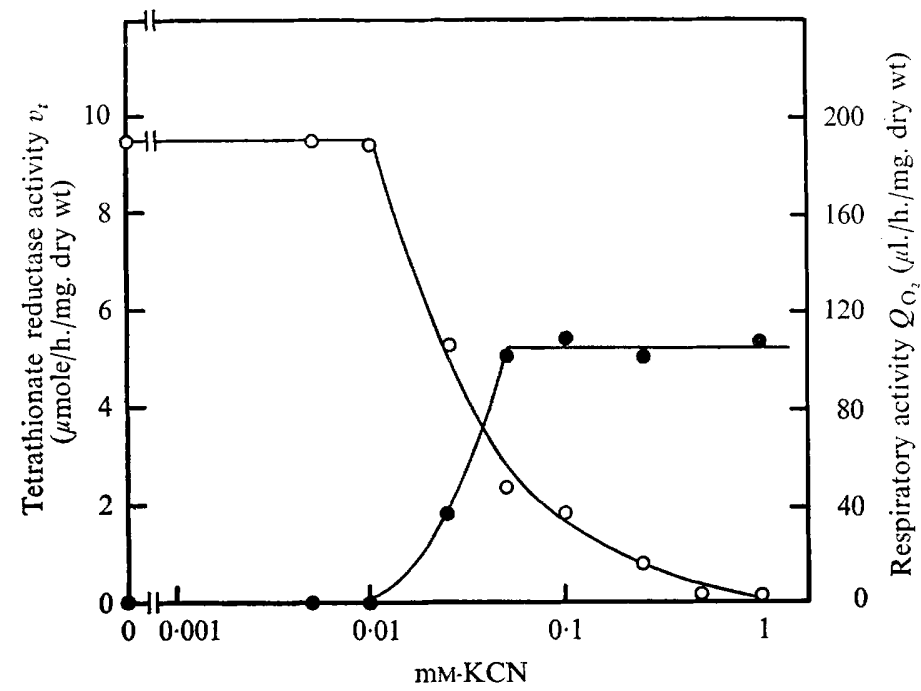

Fig. 4. Reversal by $\mathrm{KCN}$ of the inhibitory effect of oxygen on tetrathionate reductase activity as function of $\mathrm{KCN}$ concentration. $\bigcirc-\bigcirc$, Respiratory activity $Q_{\mathrm{O}_{2}}(\mu \mathrm{l} . / \mathrm{h} . / \mathrm{mg})$ : $0 . \mathrm{I} 6 \mathrm{M}$-phosphate buffer, $\mathrm{pH} 6.8$; glucose $50 \mu \mathrm{mole} / \mathrm{ml}$.; washed organisms equiv. $0.36 \mathrm{I} \mathrm{mg}$. dry $\mathrm{wt} / \mathrm{ml}$; ; chloramphenicol $50 \mu \mathrm{g} . / \mathrm{ml}$. - - Tetrathionate reductase activity $v_{t}$ ( $\mu$ mole/h./mg.) under aerobic conditions: 0.16 M-phosphate buffer, $\mathrm{pH} 6.8$; glucose $50 \mu \mathrm{mole} / \mathrm{ml}$.; washed organisms equiv. I mg. dry wt $/ \mathrm{ml}$.; $\mathrm{K}_{2} \mathrm{~S}_{4} \mathrm{O}_{6} 25 \mu \mathrm{mole} / \mathrm{ml}$; chloramphenicol $50 \mu \mathrm{g} . / \mathrm{ml}$.; final volume $20 \mathrm{ml}$.

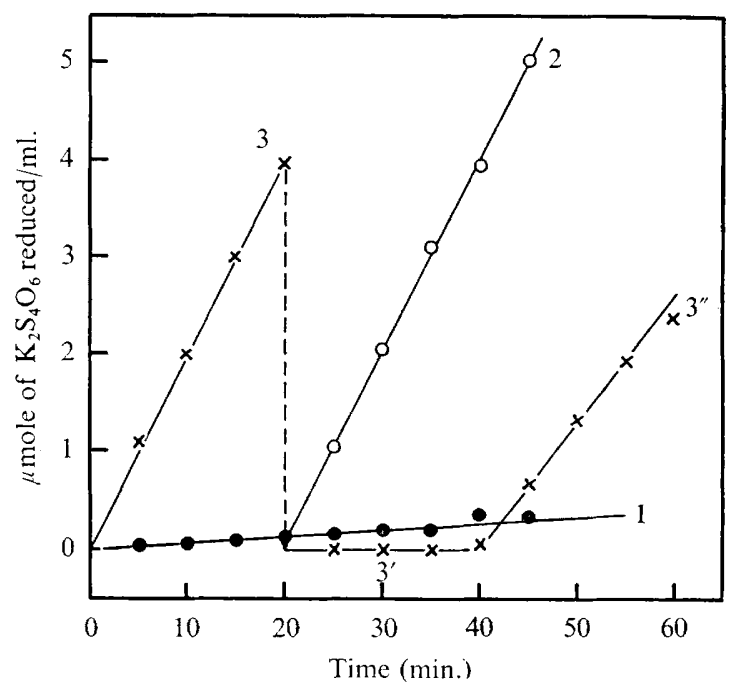

Fig. 5. Inhibitory effect of aeration on the activity of tetrathionate reductase and instantaneous and reversible removal of inhibition by cyanide. System $1: 0 \cdot 16 \mathrm{~m}$-phosphate buffer, pH 6.8; $\mathrm{K}_{2} \mathrm{~S}_{4} \mathrm{O}_{6} 25 \mu \mathrm{mole} / \mathrm{ml}$; washed organisms equiv. I mg. dry $\mathrm{wt} / \mathrm{ml}$; glucose $50 \mu \mathrm{mole} / \mathrm{ml}$.; chloramphenicol $50 \mu \mathrm{g} . / \mathrm{ml}$; aerated. System 2: the same as system I (i.e. aerated) but at $20 \mathrm{~min}$. I mM-KCN added. System 3: the same as system I (i.e. aerated) plus I mM-KCN; after $20 \mathrm{~min}$. the organisms were washed and resuspended in the same medium but without $\mathrm{KCN}\left(3^{\prime}\right)$; at $40 \mathrm{~min}$. aeration was stopped $\left(3^{\prime \prime}\right)$. 
is not the tetrathionate itself which inhibits, since $\mathrm{K}_{2} \mathrm{~S}_{4} \mathrm{O}_{6}$ did not affect the $Q_{\mathrm{O}_{2}}$ of the organisms (B) lacking tetrathionate reductase activity. The lowering of $Q_{\mathrm{o}_{2}}$, though significant, was not high and did not always occur. Its manifestation depended on the source of electrons and other factors such as the difference between $\mathrm{A}$ and $\mathrm{C}$ organisms. It was apparently conditioned by the proportions of aerobic and anaerobic respiratory activities in bacteria possessing both. The decisive fact is that oxygen may not fully inhibit the tetrathionate reductase activity in aerobic conditions.

\section{Table 2. Effect of $C O$ on respiratory activity $Q_{\mathrm{O}_{2}}$}

The composition of liquid phase in Warburg vessel: $0.16 \mathrm{~m}$-phosphate buffer, $\mathrm{pH} 6.8$; glucose $50 \mu \mathrm{mole} / \mathrm{ml}$; washed bacteria equiv. $0.3 \mathrm{I} \mathrm{mg}$. dry wt $/ \mathrm{ml}$.; chloramphenicol $50 \mu \mathrm{g} . / \mathrm{ml}$. The rate of chemical absorption of $\mathrm{CO}$ in $\mathrm{KOH}$ is subtracted, the endogenous respiration is not subtracted. The carbon monoxide was $99.995 \%$ pure (L'air liquide, Paris).

\begin{tabular}{|c|c|c|c|c|c|c|c|c|c|c|}
\hline \multirow{3}{*}{ Composition of gas phase $(\%)$} & \multirow{2}{*}{$\begin{array}{l}\mathrm{N}_{2} \\
\mathrm{CO}\end{array}$} & \multirow{2}{*}{$\overline{\text { Air }}$} & \multirow{3}{*}{$\frac{95}{5}$} & \multirow{3}{*}{$\begin{array}{r}-. \\
95 \\
5\end{array}$} & \multirow{2}{*}{90} & \multirow{2}{*}{ - } & \multirow{2}{*}{$\frac{85}{-}$} & \multirow{2}{*}{$\overline{85}$} & \multirow{2}{*}{$\frac{80}{20}$} & \multirow{3}{*}{$\begin{array}{l}\overline{80} \\
20\end{array}$} \\
\hline & & & & & & & & & & \\
\hline & $1 \mathrm{O}_{2}$ & & & & IO & 10 & I 5 & I 5 & 20 & \\
\hline $\begin{array}{l}\text { Aerobic respiratory activity } \\
Q_{\mathrm{O}_{2}}(\mu \mathrm{l} . / \mathrm{h} . / \mathrm{mg} .)\end{array}$ & & 206 & I 27 & $9 I$ & I 69 & 125 & 200 & 172 & 202 & 183 \\
\hline $\begin{array}{l}\text { Aerobic respiratory activity } \\
\text { expressed in percentage of the } \\
\text { control activity of (CO substitu } \\
\text { by } \mathrm{N}_{2} \text { ) }\end{array}$ & & - & 100 & $71 \cdot 6$ & 100 & 74.0 & 100 & 86.0 & 100 & $90 \cdot 6$ \\
\hline
\end{tabular}

Table 3. Effect of $\mathrm{CO}$ on tetrathionate reductase activity in the presence and absence of oxygen

The composition of liquid phase: $0.16 \mathrm{M}$-phosphate buffer, $\mathrm{pH} 6.8 ; \mathrm{K}_{2} \mathrm{~S}_{4} \mathrm{O}_{6} 25 \mu \mathrm{mole} / \mathrm{ml}$; glucose $50 \mu \mathrm{mole} / \mathrm{ml}$; washed bacteria equiv. I $\mathrm{mg}$. dry $\mathrm{wt} / \mathrm{ml}$.; final volume $20 \mathrm{ml}$. This solution was aerated with gaseous phases of the following composition.

\begin{tabular}{|c|c|c|c|c|c|c|c|c|}
\hline $\begin{array}{l}\text { The composition of } \\
\text { gas phase }(\%)\end{array}$ & $\left\{\begin{array}{l}\mathrm{N}_{2} \\
\mathrm{Air} \\
\mathrm{CO}\end{array}\right.$ & No aeration & $\begin{array}{l}100 \\
- \\
-\end{array}$ & $\begin{array}{l}89 \cdot 3 \\
10 \cdot 7 \\
-\end{array}$ & $\begin{array}{l}50 \\
50 \\
-\end{array}$ & $\frac{-}{100}$ & $\begin{array}{l}- \\
\text { I0.7 } \\
89 \cdot 3\end{array}$ & $\begin{array}{l}- \\
50 \\
50\end{array}$ \\
\hline The composition of & $\mathrm{N}_{2}$ & $\begin{array}{l}\text { (Anaero- } \\
\text { bically) }\end{array}$ & I. 04 & 0.93 & 0.52 & - & - & 一 \\
\hline $\begin{array}{l}\text { gas phase in partial } \\
\text { pressure (atm.) }\end{array}$ & $\begin{array}{l}\text { Air } \\
\text { CO }\end{array}$ & - & - & $\frac{0 \cdot I I}{-}$ & 0.52 & $\overline{I \cdot 04}$ & $\begin{array}{l}0.1 \mathrm{I} \\
0.93\end{array}$ & \\
\hline $\begin{array}{l}\text { Tetrathionate reduct } \\
\text { activity } v_{t}(\mu \mathrm{mole} / \mathrm{h}\end{array}$ & & $10 \cdot 3$ & $10 \cdot 3$ & $\mathrm{I} \cdot 8$ & 0.0 & 10.3 & $8 \cdot 7$ & 0.5 \\
\hline
\end{tabular}

The inhibitory effect of oxygen on tetrathionate reductase biosynthesis

The induction of tetrathionate reductase synthesis in washed non-growing organisms is shown in Fig. 6. With oxygen, as with chloramphenicol, induction did not take place. The repressive effect of oxygen on the tetrathionate reductase synthesis was reversible: after aeration ceased, induction occurred at practically the same rate as without previous aeration. The last curve excludes the possibility that inductive synthesis of reductase occurred during aeration but that its activity was inhibited by oxygen: after aeration ceased and anaerobic conditions were established in the presence of chloramphenicol (which did not influence the activity of enzyme already formed), no tetrathionate was reduced. Oxygen therefore repressed synthesis of tetrathionate reductase. Repression by oxygen did not involve ATP formed by oxidative phosphorylation in 


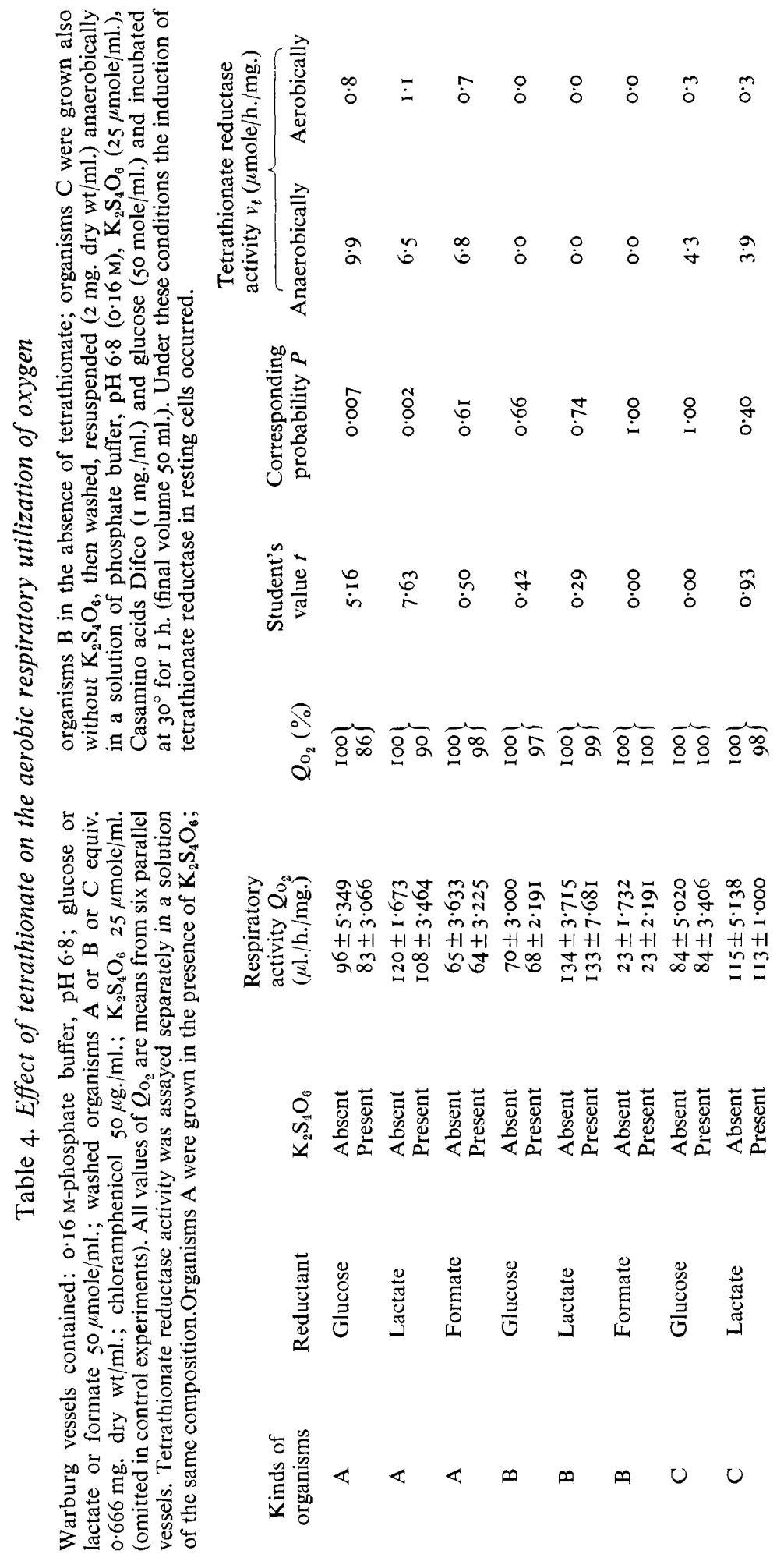


aerobiosis since no aerobic synthesis of tetrathionate reductase took place at any concentration of $2,4 \mathrm{DNP}$ (including $0.2 \mathrm{~mm}$, which we showed earlier uncoupled oxidative phosphorylation from aerobic respiration) (Fig. 7). Fig. 8 shows that oxygen repression was not reversed by $\mathrm{r}$ mM cyanide which almost completely inhibited aerobic respiration (Fig. 3). It follows that aerobic respiration was not the factor inhibiting reductase synthesis: oxygen repression occurred whether aerobic respiration was present or not.

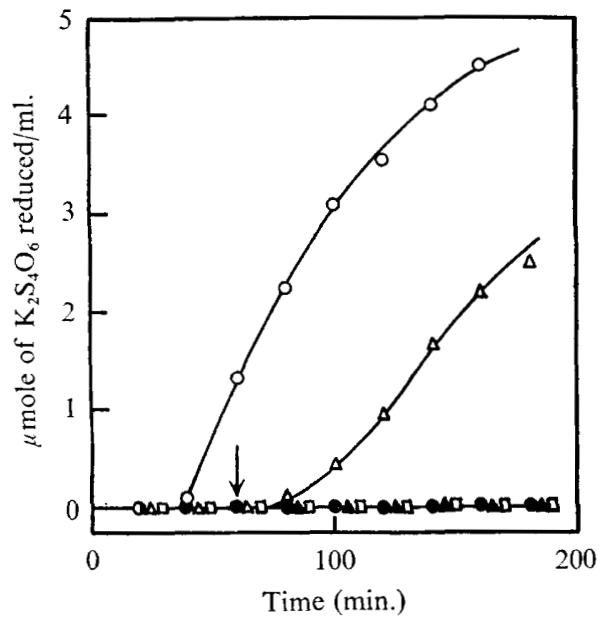

Fig. 6

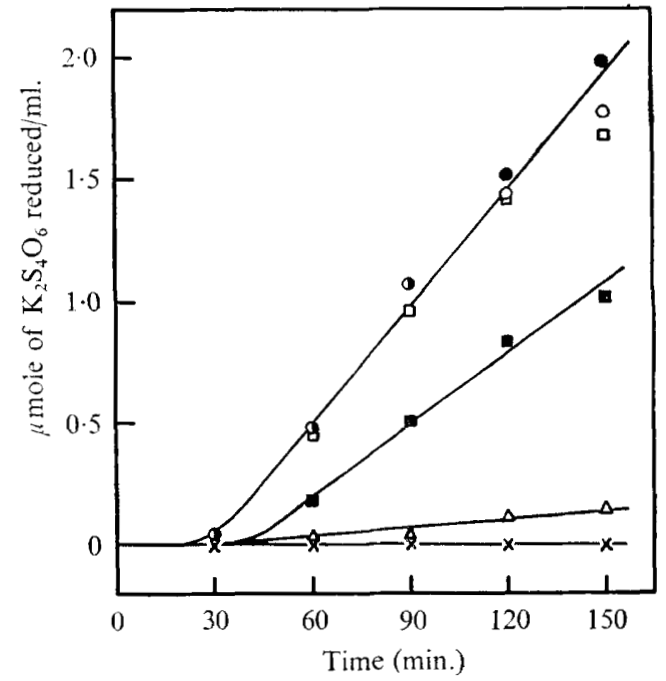

Fig. 7

Fig. 6. Induction of tetrathionate reductase synthesis in washed non-growing bacteria and the repressive effect of oxygen: 0. I I M-phosphate buffer, $\mathrm{pH} 6.8$; glucose $50 \mu \mathrm{mole} / \mathrm{ml}$.; washed organisms equiv. $2 \mathrm{mg}$. dry wt $/ \mathrm{ml}$;; $\mathrm{K}_{2} \mathrm{~S}_{4} \mathrm{O}_{6} 25 \mu \mathrm{mole} / \mathrm{ml}$.; final volume $20 \mathrm{ml}$. $\bigcirc-\bigcirc$, Anaerobically; $[\square-\square$, aerobically; -0 , anaerobically + chloramphenicol $50 \mu \mathrm{g} . / \mathrm{ml}$; $\triangle \longrightarrow \triangle$, $60 \mathrm{~min}$. aerobically, then anaerobically; $\Delta-\mathbf{A}, 60 \mathrm{~min}$. aerobically, then anaerobically + chloramphenicol $50 \mu \mathrm{g} . / \mathrm{ml}$.

Fig. 7. Induction of tetrathionate reductase synthesis in washed non-growing bacteria anaerobically and aerobically in the presence of 2,4 dinitrophenol: $0 \cdot 16 \mathrm{M}$-phosphate buffer, pH 6.8; glucose $50 \mu$ mole/ml.; $\mathrm{K}_{2} \mathrm{~S}_{4} \mathrm{O}_{6} 25 \mu$ mole/ml.; washed organisms equiv. $2 \mathrm{mg}$. dry wt/ $\mathrm{ml}$.; final volume $20 \mathrm{ml}$. $\mathrm{O}-\mathrm{O}$, Anaerobically; - a a - a robically +0.0 $\mathrm{mm}-2,4$ DNP; $\square-\square$, anaerobically + 0.I mM-2,4 DNP; $\square$, anaerobically +0.2 mM-2,4 DNP; $\triangle \longrightarrow \triangle$, anaerobically $+0.4 \mathrm{mM}-2,4 \mathrm{DNP} ; \times-\times$, aerobically $=$ anaerobically + chloramphenicol $50 \mu \mathrm{g} . / \mathrm{ml}$. = aerobically $+0.01 \mathrm{~mm}$ or $0.1 \mathrm{~mm}$ or $0.2 \mathrm{~mm}$ or $0.4 \mathrm{~mm} 2,4 \mathrm{DNP}$.

\section{DISCUSSION}

The results presented here support the idea that both terminal enzymes, the aerobic oxidase and the tetrathionate reductase, compete for electrons from a shared electron carrier:

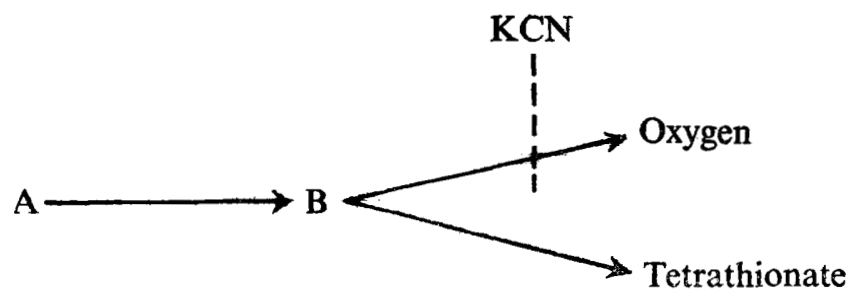


The nature of this common carrier is unknown at present, but it is insensitive to cyanide. Aerobic respiration and oxygen, as the final electron acceptor, are preferred and aerobic respiration strongly inhibits tetrathionate respiration. A preliminary analysis of the reaction kinetics in a divergent linear chain of this type shows that behaviour in accordance with our experimental findings would be exhibited by a system in which either the concentration of aerobic oxidase were tenfold to Ioo-fold greater than the concentration of tetrathionate reductase (with the same Michaelis

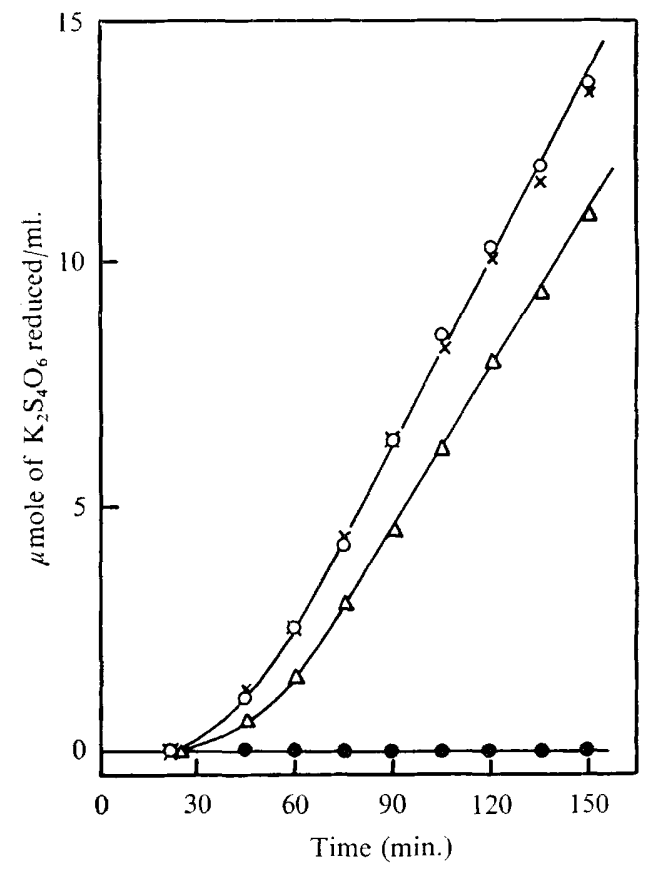

Fig. 8. Induction of tetrathionate reductase synthesis in washed non-growing bacteria anaero-

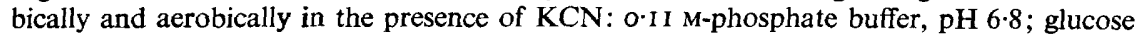
$50 \mu \mathrm{mole} / \mathrm{ml}$.; $\mathrm{K}_{2} \mathrm{~S}_{4} \mathrm{O}_{6} 25 \mu \mathrm{mole} / \mathrm{ml}$.; washed organisms equiv. $2 \mathrm{mg}$. dry $\mathrm{wt} / \mathrm{ml}$.; final volume $20 \mathrm{ml}$. $\mathrm{O} \longrightarrow \mathrm{O}$, Anaerobically; $\times \longrightarrow \times$, anaerobically $+0.1 \mathrm{~mm}-\mathrm{KCN} ; \triangle \longrightarrow \triangle$, anaerobically + I mM-KCN; - aerobically = anaerobically + chloramphenicol $50 \mu \mathrm{g} . / \mathrm{ml} .=$ aerobically $+0 \cdot \mathrm{I} \mathrm{mm}$ or $\mathrm{I} \mathrm{mm}-\mathrm{KCN}$.

constants of both toward the common electron donor), or the Michaelis constant of aerobic oxidation toward common donor is tenfold to 100-fold lower than the Michaelis constant of tetrathionate reductase at the same concentrations of both enzymes. As the rates of oxygen consumption and of tetrathionate reduction measured separately and expressed in terms of electron equivalents transferred $/ \mathrm{h} . / \mathrm{mg}$. dry wt did not differ substantially (see Fig. 3), the second possibility is more probable. Nevertheless, the degree of mutual inhibition may depend on the relative concentrations of the competing terminal enzymes (Table 4). The mode by which oxygen inhibits tetrathionate reductase activity implies that competitive electron acceptors other than oxygen should decrease the rate of tetrathionate reduction.

A part of this work was conducted while one of us (F.K.) was a visiting fellow of 
C.N.R.S. in Marseille under Professor J. C. Senez, whose interest and advice are highly appreciated. The authors are very grateful to Mrs J. Bigliardi for excellent technical assistance.

\section{REFERENCES}

Dixon, M. (1953). The determination of enzyme inhibitor constants. Biochemical Journal 55, I70-17I. Dolin, M. I. (1961). Survey of microbial electron transport mechanisms. In The Bacteria, vol. 2, p. 356. Edited by I. C. Gunsalus and R. Y. Stanier. New York and London: Academic Press.

Fowler, C. B. (I95I). The relationship between fermentation and enzymatic adaptation. Biochimica et Biophysica Acta 7, 563-573.

Gray, C. T., Wimpenny, J. W. T., Hughes, D. E. \& Mossman, M. S. (1966). Regulation of metabolism in facultative bacteria. I. Structural and functional changes in Escherichia coli associated with shifts between the aerobic and anaerobic states. Biochimica et Biophysica Acta 117, 22-32.

Gray, C. T., Wimpenny, J. W. T. \& Mossman, M. R. (1966). Regulation of metabolism in facultative bacteria. II. Effects of aerobiosis, anaerobiosis and nutrition on the formation of Krebs cycle enzymes in Escherichia coli. Biochimica et Biophysica Acta r17, 33-41.

James, W. O. (1953). The use of respiratory inhibitors. Annual Review of Plant Physiology 4, 59-90.

Kaprálek, F., Pichinoty, F. \& Riegrová, J. (I969). Kinetics of reduction of tetrathionate by intact bacterial cells. Folia Microbiologica, Praha 14, 460-469.

Knox, R., Gell, P. G. H. \& Pollock, M. R. (I943). The selective action of tetrathionate in bacteriological media. Journal of Hygiene, Cambridge 43, 147-I 58.

KNox, R. \& Polıock, M. R. (1944). Bacterial tetrathionase: adaptation without demonstrable cell growth. Biochemical Journal 38, 299-304.

LE Minor, L. (1967). Distribution de la tétrathionate-réductase chez divers sérotypes de Salmonell a Annales de l'Institut Pasteur, Paris I13, II 7-123.

Le Minor, L. \& Pichinoty, F. (I963). Recherche de la tétrathionate-réductase chez les bactéries Gram négatives anaerobies facultatives (Enterobacteriaceae, Aeromonas et Pasteurella). Annales de l'Institut Pasteur, Paris 104, 384-393.

Nicolle, P. \& Le Minor, L. (1965). Sur la présence ou l'absence de la réductase du tétrathionate dans une collection de bacilles typhiques de provenances varieés. Annales de l'Institut Pasteur, Paris ro8, $50 \mathrm{I}-5 \mathrm{I} 3$.

Papavassiliou, J., Samaraki-Lyberopoulou, V. \& Piperakis, G. (1969). Production of tetrathionate reductase by Salmonella. Canadian Journal of Microbiology 15, 238-240.

Pichinoty, F. (1965). L'effet oxygène et la biosynthèse des enzymes d'oxydoréduction bactériens. In Mecanismes de Regulation des Activités Cellularies chez les Micro-organismes, p. 507. Paris: C.N.R.S.

Pichinoty, F. \& Bigliardi-Rouvier, J. (I963). Recherches sur la tétrathionate-réductase d'une bactérie anerobie facultative. Biochimica et Biophysica Acta 67, 366-378.

PolLock, M. R. (1946). Adaptation of 'nitratase' in washed suspensions of bacteria. British Journal of Experimental Pathology 27, 419-432.

Pollock, M. R. \& KNox, R. (1943). Bacterial reduction of tetrathionate. Biochemical Journal 37, $476-48 \mathrm{I}$.

Pollock, M. R., Knox, R. \& Gell, P. G. H. (1942). Bacterial reduction of tetrathionate. Nature, London 150, 94.

RoвBE, W. A. (I946). The quantitative control of cyanide in manometric experimentation. Journal of Cellular and Comparative Physiology 27, I 8 I-209.

Sedlak, J. \& Slajsova, M. (1967). Taxonomie du coliforme I433. Annales de l'Institut Pasteur, Paris II2, I I9-I2I.

SLATER, E. C. (1963). Uncouplers and inhibitors of oxidative phosphorylation. In Metabolic Inhibitors, vol. 2, p. 503. Edited by R. M. Hochster and J. H. Quastel. New York and London: Academic Press.

Stickland, L. H. (193I). The reduction of nitrates by Bact. coli. Biochemical Journal 25, I 543-1 544 . 